\title{
TRENDS IN WEED MANAGEMENT IN NEW ZEALAND ORCHARDS
}

\author{
A.J. PEARSON \\ Crop \& Food Research, PO Box 85, Hastings, New Zealand \\ Corresponding author: pearsona@crop.cri.nz
}

\begin{abstract}
A weed management survey was distributed to New Zealand pipfruit growers in 2001 seeking information on their approaches to weed control. Results were compared with an earlier survey conducted in 1989/1990. Since 1989 orchardists have changed their approach to weed control. The width of orchard herbicide strips has not changed but the intensity of weed control has decreased with more growers prepared to accept weeds on their orchards. The use and application frequency of residual herbicides has decreased dramatically, and there has been a large increase in the number of growers using glyphosate as their only herbicide. A large number of growers are supplementing their herbicide programme with non-chemical means of weed control. Winter grazing with sheep and partial mowing of the tree line are the most popular non-chemical methods employed.
\end{abstract}

Keywords: apple, orchard floor management, weed control, herbicide, orchard understorey.

\section{INTRODUCTION}

Since 1968, a number of published surveys have outlined weed management practices in New Zealand pipfruit orchards. The last survey to cover the major fruit growing regions of Hawke's Bay and Nelson was conducted in the 1989/1990 season (Berry 1992), before the introduction in 1996 of the integrated fruit production (IFP) scheme (Batchelor et al. 1997).

The objective of the IFP scheme is the environmentally sustainable production of pipfruit. The scheme plays a key role in maintaining market access for New Zealand fruit. The soil management section of the IFP manual, which was introduced in 2000, encourages growers to adopt practices that maintain soil quality. Some weed control practices can lead to soil degradation (Haynes 1981) so efforts to improve orchard soil quality may require changes in weed management.

This study partially repeats a survey conducted in 1989/1990 (Berry 1992) and compares weed management practices then with more recent results to determine how introduction of the IFP scheme has affected weed management in New Zealand orchards.

\section{METHODS}

A survey was prepared and distributed in autumn 2001, when there was $100 \%$ adoption of IFP by non-organic growers (Anon. 2003). Key questions in the survey were directed at weed control intensity, chemical methods of weed control including type and frequency of herbicide applications, and non-chemical weed control such as grazing, mowing, cultivation or the use of mulches. Some questions were identical to those asked by Berry (1992). New Zealand Pipfruit Limited distributed the survey to all 1301 of their growers via a monthly newsletter. The survey was also distributed at a grower field day and was part of another study on orchard soil quality. As part of the orchard soil quality project, the width of tree line herbicide strips and alleyways were measured using a tape measure in 38 Hawke's Bay and Nelson orchards during autumn 2001. The width of the 
tree line herbicide strip was calculated by subtracting the width of the alleyway sward from the total distance between tree rows.

\section{Survey response}

\section{RESULTS AND DISCUSSION}

New Zealand Pipfruit Limited received a total of 49 responses. Five responses were submitted at the field day and a further 43 were compiled from the orchard soil quality project. Of the 97 respondents, 12 were managing organic orchards. The remaining 85 orchards were under IFP management. The regional distribution of respondents is given in Table 1. The total of 97 responses was similar to surveys conducted by Berry (1992) and Dastgheib \& Frampton (2000), to which 77 and 80 responses were received respectively.

TABLE 1: Number and regional distribution of respondents to the 2001 survey.

\begin{tabular}{lccc}
\hline District & No. respondents & Total no. growers $^{1}$ & \% of respondents \\
\hline Hawke's Bay & 55 & 633 & 8.9 \\
Nelson & 19 & 288 & 6.6 \\
Other North Island & 13 & 183 & 7.1 \\
Other South Island & 10 & 197 & 5.1 \\
Total & 97 & 1301 & 7.5 \\
\hline
\end{tabular}

${ }^{1}$ From New Zealand Pipfruit Limited database in 2003 (M. Butcher, pers. comm.).

\section{Intensity of weed control}

The question about weed control intensity was the same as that posed by Berry (1992) to orchardists in Hawke's Bay and Nelson. Growers were asked select a response that best described how intensively they managed weeds in the tree line (Table 2). All responded to this question. There has been a major shift in weed control intensity since the 1989/1990 survey (Table 2). Intensity of weed control has decreased and growers consider weeds more acceptable. This change in approach coincides with the introduction of the IFP scheme. The major change for growers under this scheme was a move to monitoring for pests and disease and only spraying when threshold levels were reached (Batchelor et al. 1997). Growers may have informally adapted this approach and applied it to weed management as well.

\section{TABLE 2: Response of NZ pipfruit growers (\%) to the question describing weed control intensity in the $2000 / 2001$ and $1989 / 1990$ surveys.}

\begin{tabular}{lcc}
\hline Description of weed control intensity & 2000/2001 survey & 1989/1990 survey \\
\hline Total vegetation control & 2 & 35 \\
Try to achieve bare soil but tolerate & 16 & 48 \\
some small weeds if hard to control & & \\
Don't mind occasional small weeds & 33 & 9 \\
Not too worried about weedy patches & 22 & 3 \\
Weeds are acceptable & 27 & 0 \\
Other & 0 & 5 \\
\hline
\end{tabular}

The width of tree line herbicide strips and alleyways were measured on 38 Hawke's Bay and Nelson IFP orchards during autumn 2001. The average width of alleyways was $2.5 \mathrm{~m}$ (54\% of orchard floor) and the herbicide strips was $2.2 \mathrm{~m}(46 \%$ of the orchard floor), which is very similar to those reported in other recent studies (Harrington et al. 1992; Dastgheib \& Frampton 2000). In their survey response, 18 of these 38 growers $(47 \%)$ indicated the width of the herbicide strip was reduced during the season. This 
practice is encouraged in the IFP manual as a way of introducing organic matter to the herbicide strip for maintaining soil quality.

\section{Weed control using herbicides}

Of the 85 orchards under IFP management, 72 respondents stated the types of herbicides used. The most popular herbicides were glyphosate (used by $96 \%$ of growers) and amitrole (17\%).

All IFP growers were asked how many knockdown and residual herbicide applications they made in a year, and responses were compared with the 1989/1990 survey (Table 3). While the number of annual knockdown herbicide applications has changed little, the number of residual herbicide applications has decreased from an average of 1.2 per year in $1989 / 1990$ to one application every four years in 2000/2001. The proportion of growers using residual herbicides has also decreased, from $87 \%$ in $1989 / 1990$ to $29 \%$ in 2000 / 2001.

\section{TABLE 3: Frequency of herbicide use as shown by the percentage of IFP growers applying that number of herbicides in a year.}

\begin{tabular}{lccccc}
\hline \multirow{2}{*}{$\begin{array}{l}\text { No. applications } \\
\text { per year }\end{array}$} & \multicolumn{2}{c}{ Knockdown herbicides } & & \multicolumn{2}{c}{ Residual herbicides } \\
\cline { 2 - 2 } \cline { 5 - 6 } & $2000 / 2001$ & $1989 / 1990$ & & $2000 / 2001$ & $1989 / 1990$ \\
\hline 0 & 2 & & & 71 & 13 \\
$<1^{1}$ & 11 & 6 & & 18 & 56 \\
1 & 31 & 41 & & 2 & 30 \\
2 & 41 & 40 & & & 1 \\
3 & 14 & 12 & & & \\
4 & 1 & 1 & & 100 & 100 \\
5 & 100 & 100 & & 0.25 & 1.2 \\
Total & 2.5 & 2.6 & & 0.6
\end{tabular}

${ }^{1}$ Where herbicide application is less than annual but still used, e.g. one year in three.

Of the 72 IFP growers who indicated the type of herbicides used, 57\% were using glyphosate alone, an increase from 29\% in 1989/1990 (Berry 1992). Glyphosate provides only limited control over common tree line weeds such as white clover (Trifolium repens) and broad-leaf dock (Rumex obtusifulius) which are host plants for leafroller larvae, an important pest in New Zealand orchards (Suckling et al. 1998). The sole use of glyphosate therefore has implications for both weed and pest management. Only 12 of the 72 growers used a combination of knockdown and residual herbicides for weed control.

\section{Alternatives and supplements to herbicides for weed control}

Of all growers, 10 indicated they had used one or more types of organic mulch, either as a supplement or an alternative to chemical weed control. The most popular mulch was bark or sawdust (six growers) or imported vegetation such as hay, straw, silage or grass clippings (six growers). Only four of these 10 growers were managing organic properties.

Winter grazing with sheep was more common on orchards in Hawke's Bay (64\%) than in Nelson (53\%). Dastgheib \& Frampton (2000) found 35\% of Nelson orchards were grazed in 1997/1998. Overall, 53\% of respondents in this survey used grazing for weed control, which was similar to the level reported by Berry (1992).

Organic growers commonly mow in the tree lines of their orchards to control vegetation. This practice is being adopted by some IFP growers, with $35 \%$ attempting to at least partially mow in the tree lines. This is a much higher proportion than the $7 \%$ reported by Berry (1992).

Transferring mower clippings from the alleyways to tree lines is one way of adding organic matter and nutrients to tree lines, and has demonstrable benefits for tree growth and production (Marsh et al. 1996). Fifty-six percent of growers indicated they transferred 
their clippings to the tree line. This practice appears to have increased as only a few growers were transferring their alleyway clippings five years previously (Dastgheib \& Frampton 2000). This practice has been encouraged as part of the IFP scheme (Anon. 2001), which could account for its increased popularity.

All but one grower had permanent vegetation in the orchard alleyway and that site had just been replanted. Slade (1968) reported that only $60 \%$ of New Zealand orchards had permanent swards due to the prevalence of cultivation for weed control. Cultivation was still used in alleyways in the late 1970s but a permanent sward was more common (Taylor 1979). Ten years later, permanent swards were the norm in orchards (Harrington et al. 1992). Long-term cultivation can lead to soil degradation and is discouraged under the IFP scheme.

Since 1989 New Zealand orchardists have decreased the intensity of weed control by changing the type and frequency of herbicide use. While this has benefits for soil quality in terms of organic matter inputs, there may be significant negative effects. The sole use of glyphosate for chemical weed control will increase populations of glyphosate resistant weeds, some of which are hosts for orchard insect pests. Investigation of the NZ Pipfruit spray diary database is required to confirm these findings and grower education on herbicide resistance may be necessary.

\section{ACKNOWLEDGEMENTS}

The author thanks Dr Mike Butcher (NZ Pipfruit Limited) and Heidi Stiefel (Agriculture New Zealand) for assistance in preparing and distributing of the survey, the growers who participated in this study and Ministry for the Environment for funding this study.

\section{REFERENCES}

Anon. 2001: Soil management. In: Integrated Fruit Production Manual. New Zealand Pipfruit Limited, Havelock North, New Zealand. 16 p.

Anon. 2003: NZ Pipfruit Integrated Fruit Production. www.nzpipfruit.co.nz (28/04/ 03 ).

Batchelor, T.A.; Walker, J.T.S.; Manktelow, D.W.L.; Park, N.M.; Johnson, S.R. 1997: New Zealand integrated fruit production for pipfruit - charting a new course. Proc. 50th N.Z. Plant Prot. Conf.: 14-19.

Berry, S.B. 1992: Weed control practices in New Zealand pipfruit orchards. Master of Horticultural Science thesis, Massey University, Palmerston North. 224 p.

Dastgheib, F.; Frampton, C.M.A. 2000: Weed management practices in apple orchards and vineyards in the South Island of New Zealand. N.Z. J. Crop Hort. Sci. 25: 5358 .

Harrington, K.C.; Berry, S.B.; Sims, R.E.H. 1992: A survey of weed control practices in New Zealand pipfruit orchards. Proc. 45th N.Z. Plant Prot. Conf.: 285-288.

Haynes, R.J. 1981: Effect of soil management practices on soil physical properties, earthworm population and tree root distribution in a commercial apple orchard. Soil Till. Res. 1: 269-280.

Marsh, K.B.; Daly, M.J.; McCarthy, T.P. 1996: The effect of understorey management on soil fertility, tree nutrition, fruit production and apple fruit quality. Biol. Agric. Hort. 13: 161-173.

Slade, D.A. 1968: A review of herbicide use in New Zealand orchards. Proc. 21st N.Z Weed and Pest Control Conf.: 75-81.

Suckling, D.M.; Burnip, G.M.; Walker, J.T.S.; Shaw, P.W.; McLaren, G.F.; Howard, C.R.; Lo, P.; White, V.; Fraser, J. 1998: The abundance of leafroller and their parasitoids on selected host plants in New Zealand. N.Z. J. Crop. Hort. Sci. 26: 193-203.

Taylor, R.L. 1979: Weed control in New Zealand orchards. Proc. 32nd N.Z Weed and Pest Control Conf.: 230-233. 